\title{
紙の磨耗性についで
}

\section{前書 き}

紙の磨耗性として特に印刷紙の印刷版面または辢裁 刃に対する整害は最近の輸出紙に抢ける問題として注 目されている。この磨耗の原因恃主として紙の媜料と して使用されるクレーの中に残存する石英のごとき硬 い磺物粒子汇よるものとされている。わが国製紙界で 一般飞使用されているクレーは侅石質もしくは絹雲母 質の磧石から精製したもので，いずれる激しい機橶的 粉确処理を受けているため上記のごとき硬い硔物も共 飞粉末状となって混入しているからである。

この磨耗性物質は紙料調製工程においてはビーター またはジョルダンの刃を磨耗しまた抄紙工程において は漉網，ロール，スリッターナイフなど紙として接触 する機械の金属部分飞対し，すべて磨耗的損害を与兄 るものである。これらの中特に顕著なる損耗を蒙るる のは掂網であってその使用期限を短縮し極めて不経济 的原因となるのである。また他方塗被加工用のクレー あるいはカオリンの場合にありては，この磨耗性物質 の存在は一層注視の的となる。すなわちカップロール の凹版彫刻面を削磨し，あるいはドクターブレードを 磨耗してその面を粗雑にししたがって塗被面に条痕を 䀫す害を与える。故に今後はいずれの場合に対しても この磨耗性検定規格を設定することが必須条件となっ て来るのは明かである。

\section{充㯖用クレーについて}

製紙界に执いて使用される充墫用クレーの大部分は 葉蜳石 (Pyrophyllite) すなわち䗵石から精製された もので中国地方から多く産出する。次涓雲母 (Sericite）貿硔石から精製されたものには彼の山形県板谷 のジークライト化学碳業会社のクレーがある。これは

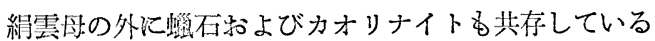
あので今日我製紙界飞多量飞供給されている。

要するにこれら地下資源はその母岩が熱水と土壤の 重玨とによりて次第にクレー化したものでその成分は 母岩の性質によりて決して単一のものでない。なおわ が国土は到る処に火山带が走りその地熱と硫父のため

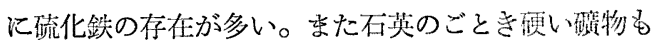

* 原稿受付 36.8 .16

** 白石工業株式会社

昭和 36 年 10 月
片倉 健 四 郎**

残存しているから採掘した原磺はまず選䃥して不良部

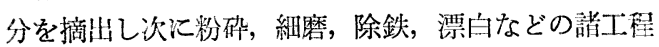
を経，また幾回かの水籍工程を通して一定粒度に分級 乙最後飞沈測槽汇導いて沈潵せしめ後脱水し乾燥する ものである。

要するにクレー製品の良否は原黉の選択と精製方法 とによるもので良質の製品には幾多煩雑なる処理が絽 没えされるゆ光費用も嵩又収率も減少する。したがっ て価格も高くなるのは当然のことである。しかる伤製 紙界の多くはクンーの重要性を余り認識せず唯価格 みのを対照として購入する悪慣習が今日な抢行なわれ ているため勢いクレー業者は精製を蹯略にせざるを得 なく延いては製紙上磨耗性の禍害となるの原因を作る ことに惯するのである。

\section{加工用クレーについて}

次に加工用クレーにありても磨耗性粒子の存在（邀 滩硅酸）は決して良しくない。わが国のアート紙, $M C$ 紙の主要顔料は現今な打䗨石質クレーの精良品を 使用しているが欧米諸国にありてはカオリンを使用す る。

カオリンには第一次すなわち残留性カオリンと第二 次すなわち沈積性カオリンの 2 系統があり, 彼のアメ リカにて代表的のジョウジャア・カオリンは第二次カ

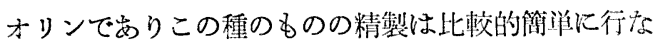
われしか子磿耗性物質は活とんど存在していない故汇 MC顔料として盛んに使用されている。しかしこのカ オリンは淡褐色を帯びているから通常漂白処理を加党 ている。

また一方英国コルンウオール産カオリンは第一次カ オリンで品質の優良な点化岕りてはジョウジャア・カ カリンに優っている。アメリカでも特殊上質アート紙 にはこのカオリンを使用しているそうである。すが製 紙界飞も最近 S.P.S 印として多少宛輸入している。

わが国に预いては上記ジョウジャア・カオリンに展 敵するカオリナイト族カオリンとしては栃木罧河内郡 の関白碳山から産する関白カオリンと北海道上士县勢 多礔山から産する勢多カオリンが共化代表的優良品で あっていずれもアート紙，MC 紙顔料として使用され ている。

その他長崎罧五島, 対島, 愛知県東郷地方拈よび長 
野景伊那地方から童出するハロイサイト，加水ハロイ サイ々が一般化カオリンと称して同一用途化仙われて

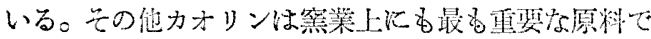

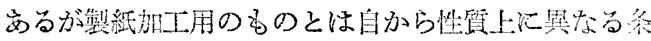

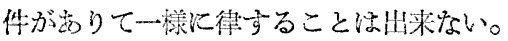

\section{充㙗用クレーの品質検查について}

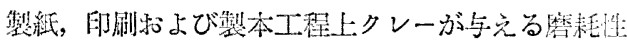
の害の軽視出来ないことはすでに冒頭に蚂いて説明し た通りで岁るからここには省略し唯害耗性の少ない縕 の製造上，傎用さるべきクレーの品筫条件沉ついて一

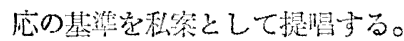

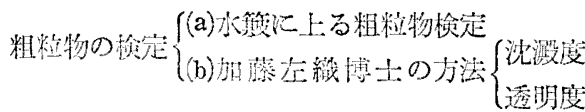

a) 供嵒品 $20 \sim 30 \mathrm{gr}$ 学ビーカーにとり少量の水走 加えよく控和しつつ次第に水起增してクレーミル

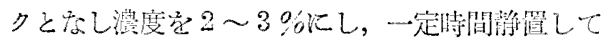
上層液の約半分定他のビーカーに假斜し次に残る

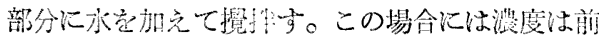
の約半分となる。かくのごとく数回反㠅し滥度が 稀薄となるにしたがって粗粒物が明かに分踓する。 しかる時この粗粒物を集め榦して科量す。上等 クレーとしては $2 \sim 3 \%$ (トン当 $¥ 13,000$ 位) 普通クレーとしてはら〜7\%（トン当 $¥ 10,000$ ) アート紙， $\mathrm{MC}$ 紙用方オリンには粗粒物 0.50 以 下である。

タイラー標潐節 200 メッシニのものは稙子玨で $74 \mu, 325$ メッシュのものは $44 \mu$ であ。紛状の

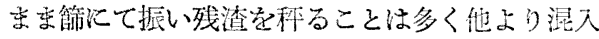
せる粗大物を検定するにとどまる。

b) 沈测度 :

クレーを5\%分泥槳液となし 30 分放置後の沈 澱部分の容䑶を見る。

透明度 :

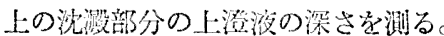

概䛨としてクレー全体が速く沈降しその谷和 が大であるるのがよい。反刘汇容䅡が小で一暗 緩慢汇沈降与る微䋖粒子の存在与るは不可。大 体沈潵度 $25 \sim 50 \mathrm{cc}$, 上澄液の透明度 $40 \sim 50 \mathrm{~m} / \mathrm{m}$ 程度ならばよいとされる。

粒度の制限 :

粒度の制限は歩止量飞影響するものであるが これはをたパルプの叫解，サイズ量，抄速，サ クションの度合などに関係する。今一般的の精 度制限を示せば大略下のごとし。

$$
\begin{array}{ll}
10 \sim 20 \mu & 85 \sim 90 \% \\
5 \sim 10 \mu & 55 \sim 65 \% \\
5 \sim 3 \mu & 55 \sim 50 \% \\
3 \sim 1 \mu & 20 \sim 30 \%
\end{array}
$$

\section{炭酸カルシウム堦料使用について}

炭酸カルシウム（略して炭カル）はアネリカに㧧い

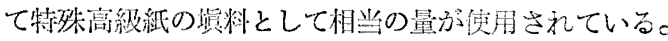
その主なる目的は白色度，不遥明の高いことならでに

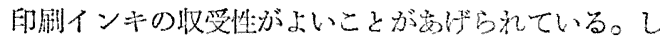
かしビーター添加の場合には普通のロジンアルミナサ イズはサイズ效果学失うのでサイロンサイズのごとき

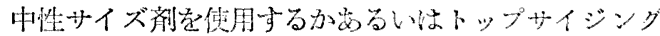
法で行なわれる。

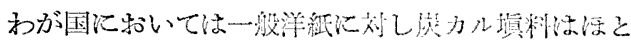
んぞ使われていない。唯ライスペーパー，インジアペ ーパーのごとき薄き無サイズ特殊紙に深川されること が主要の用途である。しかるに数年前向石亡装怢式会

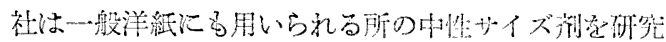
創製（特許番号第 264248）して広く慜絓罚心紹介した。 その特長とする所虫炭カルの特筫方なわち白色度，不 透明性の外，特に磨耗度の少ない紙の䳌造に好直与る 点を強調したので岕る。な敃微粉タルク起少量混用与

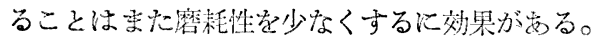

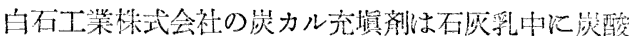
ガスを吹込んで造ったもので精子はきるめ微細で蚛

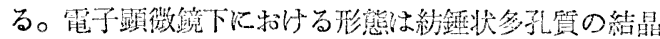

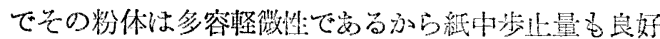

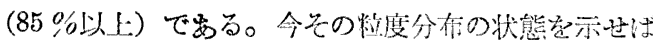
次のごとし

$\begin{array}{lrr}1 \quad \text { " 以下 } & 7.2 \\ 1 \sim 3 \mu " ~ & 66.8 \\ 3 \sim 5 \mu " & 17.4 \\ 5 \quad \mu \text { 以上 } & 8.6 \\ \text { pH } & & 9.8\end{array}$

また近䪸重質炭カル（微粉整品）が市場に見われてい るがこのものは粒子が中宾，球状にして見掛比重は势 微性炭力ルの 2 倍定有し沈降速度速く距料汶刘する步

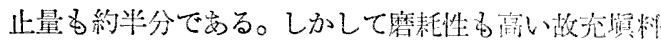

\begin{tabular}{|c|c|c|c|c|}
\hline 白色度 ${ }^{1)}$ & 98 & 98 & 96 & 93 \\
\hline 比 & 2.60 & 2.60 & 2.70 & 2.70 \\
\hline 見掛比重 $\mathrm{g} / \mathrm{cc}^{2}$ & 0.47 & 0.52 & 1.00 & 1.07 \\
\hline
\end{tabular}
としては不可で岕。

炭酸カルシウムの物理的性暨

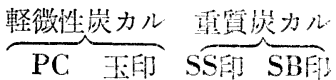




\begin{tabular}{|c|c|c|c|}
\hline 平均粒子径 $\mu^{3)}$ & 1.0 & 1.4 & 1.5 \\
\hline 比薮面積 $\left.\mathrm{m}^{2} / \mathrm{g}^{4}\right)$ & 6.0 & 4.8 & 3.5 \\
\hline $\left.\mathrm{P} \quad \mathrm{H}^{5}\right)$ & 9.0 & 9.2 & 8.8 \\
\hline
\end{tabular}

1) 光電色沢計により搪散反射率在湘定

2) 充坥して測定

3) 霓顕写真加与测定した产均粒子整

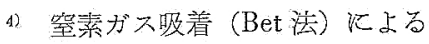

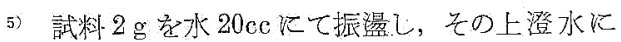
C砖定

\section{炭カル垻料に対する中性サイズ咸の効用}

本サイズ斉の主体はコロホニー樹脂を苛性ソーダ岁

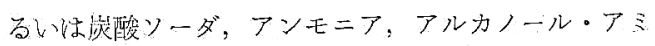

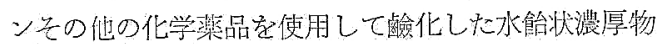
て国形分 40〜 45\%を含有している。その使用に祭し

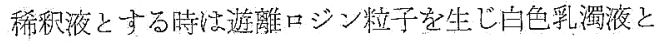
なる。しか子それらの粒子は微細状態保たれ，䋊に 刘するサイズ效果は高く，サイズ量等莭し得ると同 時飞明バン星をる大火穊的することが出来る。

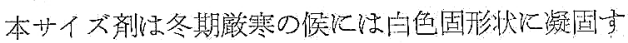

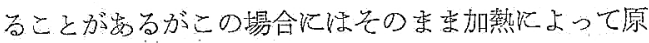

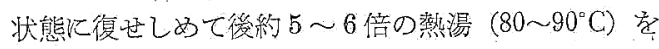

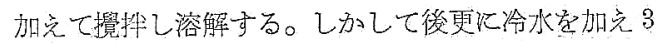
〜 4\%濃度桸秎し調合室タンクに送り紙料のサイジ ングに供する。

サイズの方法は吅解パルプに中性サイズ液を加党次

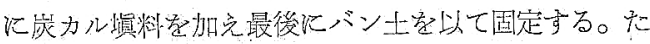
たし pH 7.0の中性点で止るる。宸かル中性サイズ紙

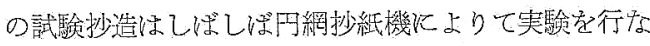

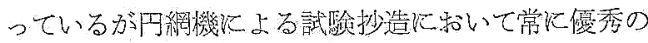

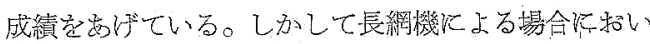
ては唯蹐いサクションのためにサイズ度に両面性を現 わしサイズ度の低下を起可大点が見受故れた。

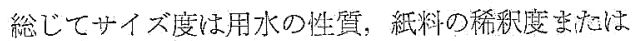
ドライナーに大る眭のウエットウェッブの脱水度に影

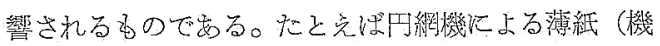

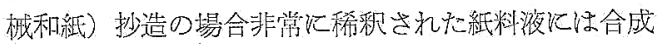
䞑脂ニーラミンP 1700 岁るいはベッカミンのごとき

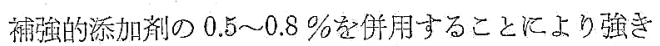

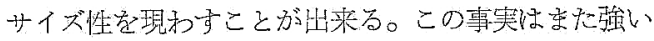
サクッョンの下長絧機の揚合にる適用して效果が認め

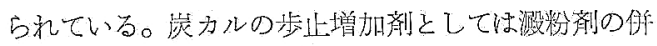

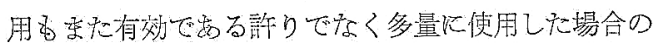
絓粉防止にも役立つるのである。

紙征般に酸性サイズルよりて固定されているが紙 の理想的サイズとしては中性焉るいは微アルカリ性サ
イズの方が紙の保存性，印刷インク乾䑁性より要望さ

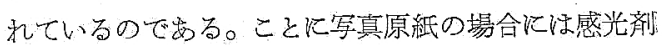
との関係に良好なる結果を覞するのである。

ここ湠カルとクレーの価格差については前者の呧 当¥ 18 亿比し後者の $¥ 13$ は生産コストの面加ら普通

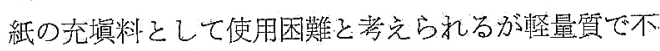
透明の紙たとえば航空用筆記，印刷，封衙用紋，複写 伝票用紙，辞典用縕のごとき特放上質紙類に将十分採 算的となる。故に今後は加加る方面の新絓類開拓飞打 適稀。

崖カルは李たクレーと混合して子差支ない（唯クレ

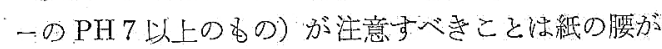

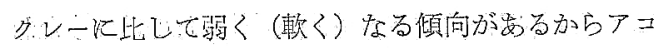
ストレングスのごと補強郕を併用することが旺しい。 その他『脂とり化粧紙』用として炭カル，炭マグある

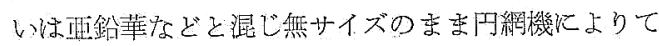
抄造することす大推奖する価值がある。しかて查 料性上後们加し気密包装要する。

\section{クレーの磨度検定について}

整耗度检定器としてアメリカに特いて採用されてい

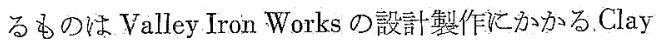
Abrasion Tester である。同器は付図に示すごとさ装

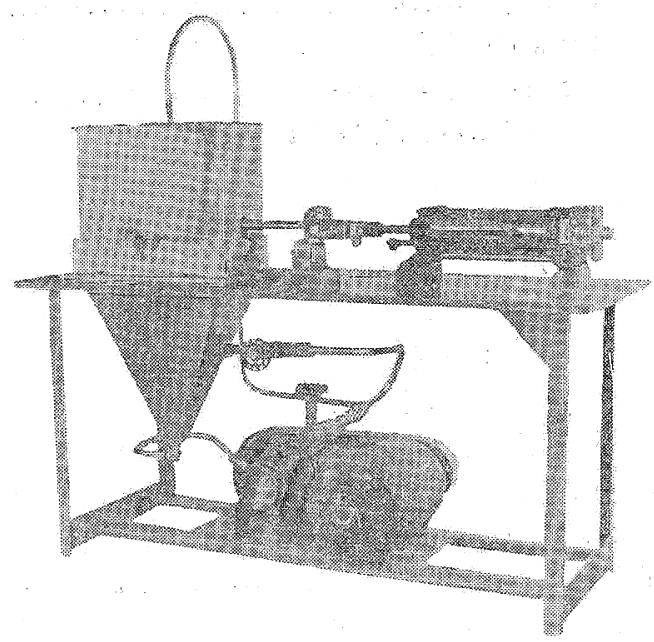

置にして，一定濃度のクレーの奬濁液をしてまる一定

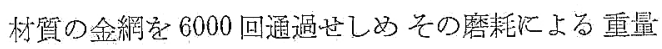

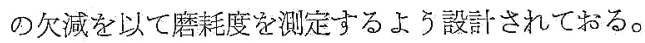

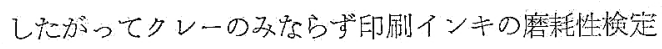
用炕事応用すること势出来る。

本器の取技法

1) ポンプ和よび循環系統に清水を流して清潔に洗 雀する。 
2）回転数表示機を Oに㯰き新に正確に科量した清 浄試験金網を枠に取付ける。この際スプラッシニ パン，ホッパーおよび連絡桿は一特取外しておく。

3）供試料たるクレーは $75 \mathrm{gr}$ を科量し， $3200 \mathrm{cc} の$ 蒸溜水 $\left(22^{\circ} \mathrm{C}\right)$ を以て泥漿液とし往復運動する木 ッパーに注ぎ，一方ポンプのスウイッチを入れる。 この際小時間泥漿液を流動させて混合状態を均一 にする。次空気系のバルブを關いてェーヤ・モ ーターを始動させる。（この際スプラッユパンか ら溢れるようバイパッスのバルブを調整する)

4）回転計が 6000 サイクル（12000ストローク） を示したならば，運動を止め供試金網を取外し， 注意して秤量する。金網の原重量との差はすなわ ち供試クレーの磨耗度として表わされる。

5）循環用ポンプはインペラー型で容量は 1 分間当 り 1 1/2ガロンである。試験には約 1 リットルの クレー泥漿液が使用される。な打本機を液体なし で運転することは避ること。

6）エーヤーモーターは 1 分間 85 サイクル (170ス トローク）で運転するよう調整すること。（毎回 の試験前に本機のストロークがこの数になるよう 調整する)エーヤーモーターは $60 \mathrm{psi}$ で作動する。

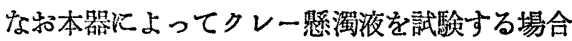
には予め水に上る空白試験を同一方法によって行

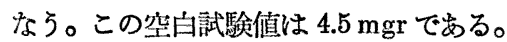

\begin{tabular}{|c|c|}
\hline ジョージャ・クレー & $4.1 \sim 9.7$ (平均 5.5 ) \\
\hline 英国産コーチング・クレー & -5.9 \\
\hline 英国産充墤用クレー & 33.5 \\
\hline 沈降性炭酸カルシウム & 9.4 \\
\hline タルク & 144.0 (平均) \\
\hline 二酸化チタン（製紙用） & 32.4 \\
\hline 煆焼クレー（市販品） & 74.2 \\
\hline 椵焥カオリン特級品 & 52.0 \\
\hline 沈降性硫酸バリウム & 非常に低い \\
\hline
\end{tabular}
この一連の試験注いててクレー（英国産充填用クレー を除く), 沈降性炭酸カルシウムおよび沈降性䟽酸バ リウムはいずれる低い磨耗度を示しまた二酸化チタン は中級のるのである。クレーは烺燒すると約 10 倍の 高磨耗度となる。

\section{後書 き}

製紙上クレーは充垻料として重要な役割を荷なって いるにもかかわらず洋絓製造開始以来 70 80 年の長 い間これ関する研究は医とんどなされていない。乙 たがって随分と粗悪なクレーが使われていた時代が長 く続き，これがため抄絓機の雁網，ロール，ナイフ類 に磨耗性の損害を与えていたことは蓋し莫大な金額に 上るるのと考觉られる。

第 2 次大戦後上質紙の輸出が盛になるに拈よびこの 磨耗性のことが取引上の間題となりしばしばクレーム がつくので，ここにようやく粗恶クレーに原因するこ と汇気付いた状態である。

私は終戦後某工場にて漉網の使用期限が非常に低下 して㥗んでいるのでクレーを検查したところ粗粒物 17〜18\%を含有していた。直ちに品質のよいるのにし たところ（6〜7\%のすの）約 $50 \%$ 以上使用期限が 延長したので多大の感謝を受けた事害がある。そこで いかにこの磨耗性物質の被害が甚大であるかが察知出 来る。

また一方大戦後アメリカ技術の紹介に伴ない総ての 紙類の品質が急激に改善されことにマシン・コーチン グ技術と機珹が導入せらるるに拉よびクレー，カオリ ンに対する研究の必要性に迫られ，次第に盛んになっ てきたことは真とに善ばしい。

かような状態であるゆえ今後はクレーの品質改善を 計りて磨耗性の被害を出来るだけ最小限度に止めるこ とを切望してやまない次第である。

\section{参考文 献}

(1) 㐭料用および加工用カオリンクレーについて 片倉健四郎編 炤和 35 年 4 月

(2) 中性サイズ剂化ついて 紙パ技協誌 Vol. 12, No. 5, 1958 (炤和 33 年)

(3) 中性サイズについて 紙パ技術協会 特集Q号 昭和 34 年 3 月

(4) 炭酸カルシウムの物理的性貿：Filler Book 白 石工業 KK編 1961 版（昭和 36 年版） その他白石工棠株式会社研究報告等 